\title{
ONE-STAGE REVISION SURGERY FOR INFECTED MEGAPROSTHESES
}

\author{
G. HOLZER, R. WINDHAGER, R. KOTZ \\ From the University Clinic for Orthopaedics, Vienna, Austria
}

We have reviewed the results of one-stage revision surgery in 18 patients for infection of megaprostheses implanted after the resection of malignant bone and soft-tissue tumours.

At a mean follow-up of $\mathbf{5 2 . 0} \pm \mathbf{3 5 . 0}$ months (18 to 135) infection was eliminated in 14 of the 18 patients. The infection-free patients showed no abnormal tests for inflammation and had a mean Enneking score of 20.6 \pm 5.0 points (maximum 30 points).

We suggest that one-stage revision without exchange of the anchorage parts is justified in patients with megaprostheses infected by antibiotic-sensitive micro-organisms.

J Bone Joint Surg [Br] 1997;79-B:31-5.

Received 5 August 1996; Accepted 18 September 1996

Since the introduction of neoadjuvant chemotherapy in $1975^{1}$ for the treatment of primary and secondary tumours of bone and soft tissues, an increasing number of limbsalvage operations have been performed. In most cases preoperative shrinking of the tumour by neoadjuvant cytotoxic chemotherapy (NCC) enables tumour resection with wide margins. To bridge the bone defect, endoprostheses, ${ }^{2-6}$ biological reconstruction with osteoarticular allografts, allograft arthrodesis ${ }^{7-9}$ or rotationplasty ${ }^{10}$ may be used.

We have used megaprostheses for limb-salvage surgery since 1976. Although we started with custom-made endoprostheses we now principally use the Kotz Modular Femur Tibia Reconstruction (KMFTR) system $^{3}$ and its successor, the Howmedica Modular Reconstruction system (HMRS) (Howmedica GMBH Schönkirchen/Kiel, Germany). ${ }^{11}$

G. Holzer, MD, Orthopaedic Surgeon

R. Windhager, MD, Associate Professor

R. Kotz, MD, Chairman and Professor of Orthopaedics

University Clinic for Orthopaedics, Währinger Gürtel 18-20, A-1090

Vienna, Austria.

Correspondence should be sent to Professor R. Kotz.

(C)1997 British Editorial Society of Bone and Joint Surgery 0301-620X/97/17139\$2.00
Despite highly-developed endoprosthetic technology and extremely careful surgical techniques there are complications such as wound dehiscence, neurapraxia, soft-tissue contractures, mechanical failure, dislocation and loosening. The two most serious complications are local tumour recurrence and infection.

Extensive soft-tissue resection as well as pre- and postoperative cytotoxic chemotherapy ${ }^{12}$ increase the risk of deep infection; the reported rates for deep infection of megaprostheses are from $2.9 \%$ and $9.7 \% .^{5,12-17}$ In addition to the problems known to follow conventional hip and knee replacement surgery, the revision of infected megaprostheses has specific problems caused by the extent of the infection and tissue necrosis. In infected THRs and TKRs either one- ${ }^{18-24}$ or two-stage revision ${ }^{25-31}$ using antibioticloaded bone cement is recommended. If all the components are not exchanged the failure rate is extremely high ${ }^{25}$.

We decided to perform one-stage revision in tumour patients with infected megaprostheses without exchange of the anchorage components, provided that they were well fixed to bone. The advantages are the avoidance of temporary gross instability, less suffering for the patient, a shorter period of hospitalisation and lower costs.

We made a retrospective study of the results of one-stage revision surgery for such infected megaprostheses.

\section{PATIENTS AND METHODS}

Between January 1979 and December 1993, we implanted 336 megaprostheses for limb salvage after the resection of benign and malignant bone and soft-tissue tumours. Deep infection occurred in 19 patients $(5.7 \%)$ after a mean of $13.1 \pm 15.7$ (SD) months ( 1 to 60 ). Of these, 18 had onestage and one had two-stage revision. There were nine women and nine men having one-stage revision with a mean age at the time of limb-salvage surgery of $26.5 \pm 18.6$ years (9 to 70$)$. The mean follow-up was $52.1 \pm 35.0$ months (18 to 135 ).

The histological diagnosis had been osteosarcoma in nine patients, Ewing's sarcoma in three, and leiomyosarcoma, liposarcoma and malignant fibrous histiocytoma in one each. Three had been treated for metastases from hypernephroma, thyroid cancer and ameloplastic odontoblastoma respectively. The sites of tumour resection and endoprosthetic replacement and clinical details are given in Table I. 
Table I. Details of the 18 patients with infection of megaprostheses implanted for limb salvage

\begin{tabular}{|c|c|c|c|c|c|c|c|c|c|c|c|c|}
\hline & Age & & $\begin{array}{l}\text { Infection } \\
\text { delay }\end{array}$ & & & & $\begin{array}{l}\text { Antibiotic } \\
\text { course }\end{array}$ & F-U & WBC & CRP & ESF & \\
\hline Case & $(\mathbf{y r})$ & Sex & (mth) & Chem* & Location & Micro-organisms $\dagger$ & (mth) & (mth) & $\left(\times 10^{9}\right)$ & $(\mathrm{mg} / \mathrm{l})$ & 1 & 2 \\
\hline 1 & 10 & $\mathrm{M}$ & 6 & CESS & Distal femur & Staph epidermidis & 4 & 51 & 7.8 & 44.0 & 32 & 65 \\
\hline 2 & 25 & $\mathrm{~F}$ & 60 & CWSS & Prox femur & Staph aureus & 3 & 135 & 5.0 & 16.0 & 24 & 36 \\
\hline 3 & 16 & M & 1 & COSS & Prox tibia & Staph aureus & 3 & 18 & 6.0 & 15.9 & 51 & 71 \\
\hline 4 & 16 & M & 7 & COSS & Distal femur & Coag-neg & 3 & 45 & 5.6 & 1.0 & 5 & 12 \\
\hline 5 & 19 & M & 30 & COSS & Total femur & Strept & 5 & 26 & 5.0 & 5.0 & 3 & 7 \\
\hline 6 & 9 & $\mathrm{~F}$ & 26 & COSS & Distal femur & Coag-neg & 7 & 33 & 4.0 & 17.0 & 18 & 35 \\
\hline 7 & 14 & $\mathrm{~F}$ & 11 & COSS & Prox tibia & Staph aureus & 30 & 45 & 5.8 & 19.4 & 35 & 78 \\
\hline 8 & 10 & M & 10 & COSS & Prox tibia & Staph epidermidis & 3 & 62 & 6.8 & 5.0 & 1 & 1 \\
\hline 9 & 41 & M & 14 & COSS & Distal femur & Coag-neg & 3 & 49 & 5.8 & 24.0 & 8 & 12 \\
\hline 10 & 31 & M & 7 & CESS & Total humerus & Staph epidermidis & 8 & 23 & 6.7 & 15.0 & 70 & 115 \\
\hline 11 & 63 & $\mathrm{~F}$ & 1 & - & Total humerus & Coag-neg & 3 & 18 & 7.7 & 13.4 & 19 & 42 \\
\hline 12 & 58 & M & 18 & - & Prox femur & Staph aureus & 3 & 111 & 6.9 & 8.0 & 15 & 45 \\
\hline 13 & 31 & M & 6 & COSS & Prox tibia & Gram-pos coccus & 4 & 48 & 7.3 & 8.2 & 3 & 8 \\
\hline 14 & 70 & $\mathrm{~F}$ & 1 & CWSS & Distal femur & Staph epidermidis & 1 & - & - & - & - & - \\
\hline 15 & 17 & $\mathrm{~F}$ & 8 & COSS & Distal femur & No growth & 9 & 105 & 4.9 & 5.0 & 9 & 14 \\
\hline 16 & 15 & $\mathrm{~F}$ & 2 & coss & Distal femur & Staph epidermidis & 3 & 32 & - & - & - & - \\
\hline 17 & 16 & $\mathrm{~F}$ & 1 & COSS & Distal femur & E coli & 3 & 32 & - & - & - & - \\
\hline 18 & 16 & $\mathrm{~F}$ & 39 & T6T2 & Prox femur & No growth & 3 & - & - & - & - & - \\
\hline
\end{tabular}

*Chemotherapy see text

$\dagger$ see text

All revisions were done by one of the senior authors (RW and RK).

In addition to surgical treatment, 15 patients received NCC; five had radiation therapy and four had NCC and radiation. Eleven of the 15 were treated according to the Cooperative Osteo-Sarkom Studie (COSS) protocol, ${ }^{32}$ two had the Cooperative Ewing-Sarkom Studie (CESS) proto$\mathrm{col}^{33}$ and two the Cooperative Weichteil-Sarkom Studie (CWSS) protocol. ${ }^{34}$ One other patient had the Rosen T6T2 protocol. $^{35}$

We performed aspiration of periprosthetic fluid for microbial culture at the time of admission although all the patients had already received some antibiotic therapy. The intravenous administration of antibiotics was continued after successful aspiration. In 16 patients the micro-organism was verified by culture of the infected periprosthetic fluid. Staphylococcus epidermidis was found in five patients, Staphylococcus aureus and coagulase-negative staphylococci in four patients each and streptococci, Escherichia coli and Gram-positive cocci in one each. In the remaining two patients no organisms could be cultured. Histological examination of the tissue showed chronic purulent infection in all patients.

All patients received pre-, peri- and postoperative antibiotic chemotherapy according to sensitivity tests for a mean of $5.9 \pm 6.7$ weeks ( 3 to 30 ). The antibiotics were given parenterally during hospitalisation and then orally for longterm treatment.

Operative technique. Initially, all exchangeable compo- nents and all polyethylene parts, but not the anchorage components, were removed. Subsequently, excision of dead bone and thorough debridement of the soft tissues were performed. Povidone iodine (Betaisodona Lösung; Mundipharm GmbH, Limburg/Lahn, Germany) was used to rinse the wound thoroughly and to scrub the anchorage components carefully.

In recent one-stage revisions we have used the method of Göksan and Freeman, ${ }^{26}$ packing povidone iodine sponges into the wound before a provisional closure. The area of surgery was again disinfected, the patient redraped and the entire operating team changed gowns and gloves. After reopening the wound and removing the sponges, thorough rinsing was again performed with saline and the anchorage components again cleaned with povidone iodine.

The removed metallic KMFTR or HMR System prostheses were resterilised and reimplanted, or new components were used. Polyethylene components were not reused. The wound was closed in layers after the insertion of at least two deep suction drains and the joint was immobilised in a cast for one to two weeks.

During April 1996, 14 patients were reviewed. Four of the 18 had died, three from their primary disease. Two of these had lung metastases at the time of surgery and one died from sepsis. For these the latest recorded follow-up data were used for evaluation.

The criteria of Enneking et $\mathrm{al}^{36}$ were used for clinical evaluation. These include, for the upper extremity: pain, function, emotional acceptance, hand positioning, and man- 
ual dexterity. For the lower extremity; pain, function, emotional acceptance, supports, walking ability, and gait. This provides a numerical rating system (maximum 30 points) for statistical analysis. Radiographs were assessed according to the ISOLS system for assessment of prostheses (bone remodelling, interface, anchorage $)^{37}$ and inflammation was assessed by measurement of the ESR and C-reactive protein (CRP) and leucocyte levels. Successful eradication of infection was defined as the absence of clinical signs of sepsis and inflammation for at least six months.

For statistical analysis we used Student's $t$-test (mean, $\mathrm{SD}$, range).

\section{RESULTS}

Infection was eradicated in 14 of the 18 patients. One patient (case 14) died from sepsis during cytotoxic chemotherapy one month after a one-stage revision. Another (case 18) asked for hip disarticulation because of complete palsy of the sciatic nerve after three failed revisions. Two (cases 7 and 10) had draining fistulae at follow-up despite longterm antibiotic therapy.

Clinical findings (Table II). At follow-up the average total Enneking score was $19.8 \pm 5.2$ points $(10$ to 27$)$. The 14 patients free from infection had a score of $21.3 \pm 4.4$ points (15 to 27) and the two infected patients (cases 7 and 10) scored 16 and 10 points, respectively. Individual criteria in the non-infected patients with replacements of the lower limbs were: pain $4.0 \pm 0.8$ points, function $2.8 \pm 1.2$, emotional acceptance $4.8 \pm 0.4$, support $3.6 \pm 1.9$, walking ability $3.6 \pm 0.9$ and gait $2.5 \pm 1.3$.

Radiological findings (Table II). Anteroposterior and lateral radiographs of the anchorage components of 16 patients were obtained at the most recent follow-up and compared with those taken immediately after the revision operation. Radiological assessment, according to the ISOLS criteria for bone remodelling, showed excellent and good results in eight patients $(50 \%)$, fair in six $(37.5 \%)$ and poor in two $(12.5 \%)$. The bone-prosthesis interface was found to be excellent in 13 patients $(81.25 \%)$ and fair in three $(18.75 \%)$. The anchorage of the prosthesis was rated excellent in 15 patients $(93.75 \%)$ and fair in one $(6.25 \%)$. There were no failures of the stems of the prostheses or screw fractures. There were no radiological differences between the infected and non-infected patients.

Laboratory findings. At follow-up, the ESR was measured and CRP and leucocyte levels determined for 14 patients. In the infection-free patients the mean ESR was $15.7 \pm$ $14.6 \mathrm{~mm}$ in the first hour (ESR 1) and $29.0 \pm 423.5 \mathrm{~mm}$ in the second hour (ESR 2) with one patient in the elevated range $(51 \mathrm{~mm}$ and $71 \mathrm{~mm})$. In one of the two infected patients the ESR was 35 and $70 \mathrm{~mm}$, and in the other $78 \mathrm{~mm}$ and $115 \mathrm{~mm}$. The mean CRP in the infection-free patients was $14 \pm 12 \mathrm{mg} / \mathrm{l}$. It was elevated in the two infected patients (cases 7 and 10) to 19.4 and $15 \mathrm{mg} / \mathrm{l}$, respectively. The mean leucocyte level was $6.0 \pm 1.2 \times 10^{9}$ cells, with all patients within the normal range.

\section{DISCUSSION}

Infection is a serious complication after limb-salvage surgery using endoprosthetic replacement. After total conventional joint arthroplasty, one-stage ${ }^{18-24}$ or two-stage revision with complete exchange of all prosthetic components with the use of antibiotic-loaded bone cement ${ }^{25-31}$ is usually, recommended. In patients who have had revision

Table II. Enneking score and radiological assessment at follow-up in 16 patients. Cases 14 and 18 were not seen at follow-up

\begin{tabular}{|c|c|c|c|c|c|c|c|c|c|c|c|c|}
\hline Case & Pain & Function & $\begin{array}{l}\text { Emotional } \\
\text { acceptance }\end{array}$ & Support & Walking & Gait & $\begin{array}{l}\text { Hand } \\
\text { position }\end{array}$ & $\begin{array}{l}\text { Manual } \\
\text { dexterity }\end{array}$ & Lifting & $\begin{array}{l}\text { Bone } \\
\text { remodelling* }\end{array}$ & Interface* & Anchorage* \\
\hline 1 & 5 & 2 & 5 & 5 & 4 & 4 & & & & $\mathrm{P}$ & $\mathrm{F}$ & $\mathrm{E}$ \\
\hline 2 & 4 & 2 & 5 & 1 & 3 & 1 & & & & G & $\mathrm{E}$ & $\mathrm{E}$ \\
\hline 3 & 2 & 3 & 5 & 5 & 5 & 4 & & & & $\mathrm{~F}$ & G & $\mathrm{E}$ \\
\hline 4 & 5 & 3 & 5 & 5 & 4 & 3 & & & & $\mathrm{~F}$ & G & $\mathrm{E}$ \\
\hline 5 & 5 & 2 & 4 & 5 & 4 & 4 & & & & G & $\mathrm{E}$ & $\mathrm{E}$ \\
\hline 6 & 4 & 4 & 4 & 5 & 3 & 3 & & & & $\mathrm{~F}$ & $\mathrm{~F}$ & $\mathrm{~F}$ \\
\hline 7 & 3 & 0 & 3 & 3 & 3 & 1 & & & & $\mathrm{~F}$ & $\mathrm{~F}$ & $\mathrm{E}$ \\
\hline 8 & 4 & 4 & 5 & 5 & 5 & 3 & & & & $\mathrm{P}$ & $\mathrm{E}$ & $\mathrm{E}$ \\
\hline 9 & 3 & 4 & 5 & 1 & 3 & 1 & & & & $\mathrm{E}$ & $\mathrm{E}$ & $\mathrm{E}$ \\
\hline 10 & 3 & 0 & 3 & & & & 0 & 2 & 2 & $\mathrm{G}$ & $\mathrm{E}$ & $\mathrm{E}$ \\
\hline 11 & 5 & 1 & 4 & & & & 1 & 4 & 2 & $\mathrm{E}$ & $\mathrm{G}$ & $\mathrm{E}$ \\
\hline 12 & 4 & 1 & 5 & 1 & 3 & 1 & & & & $\mathrm{~F}$ & $\mathrm{E}$ & $\mathrm{E}$ \\
\hline 13 & 4 & 2 & 5 & 5 & 4 & 2 & & & & $\mathrm{~F}$ & $\mathrm{G}$ & $\mathrm{E}$ \\
\hline 15 & 4 & 5 & 5 & 5 & 4 & 4 & & & & $\mathrm{G}$ & $\mathrm{G}$ & $\mathrm{E}$ \\
\hline 16 & 4 & 2 & 5 & 2 & 3 & 1 & & & & $\mathrm{G}$ & $\mathrm{E}$ & $\mathrm{E}$ \\
\hline 17 & 4 & 2 & 4 & 2 & 2 & 2 & & & & $\mathrm{E}$ & $\mathrm{E}$ & $\mathrm{E}$ \\
\hline
\end{tabular}

* $\mathrm{E}=$ excellent; $\mathrm{F}=$ fair; $\mathrm{G}=$ good; $\mathrm{P}=$ poor 
of infected megaprostheses, several additional problems are related to the use of chemotherapy or radiation or both and to the large bone defects and large infected areas associated with tissue necrosis. A more aggressive approach is required. Results after the revision of infected conventional replacements are reported to be influenced by the delay between the onset of infection and revision surgery, the type of chemotherapy and the cementless or cemented fixation of the prostheses.

Deep infections in patients with megaprostheses require treatment by surgical methods because the long-term administration of antibiotics alone is not sufficient. The methods which have been described include irrigation without revision of the prosthesis, ${ }^{7}$ wound debridement without revision of the prosthesis, ${ }^{13,16,23}$ revision of the prosthesis, ${ }^{13}$ two-stage revision with implantation of a cement spacer, $^{23,38}$ arthrodesis with a vascularised fibular graft $^{13}$ and ultimately in some cases amputation. ${ }^{5,13,14,16,17}$ There are few data on the outcome of these different procedures. We decided to perform one-stage revision without exchange of the anchorage components. The advantages are the avoidance of large bone defects, the need for only one operation putting a smaller burden on the patients, a shorter period of hospitalisation and the potential for lower costs.

Patients treated with NCC have more complications than those receiving no chemotherapy or only adjuvant chemotherapy. ${ }^{12}$ All except two of our patients had been given NCC, but in two only did infection appear to start during

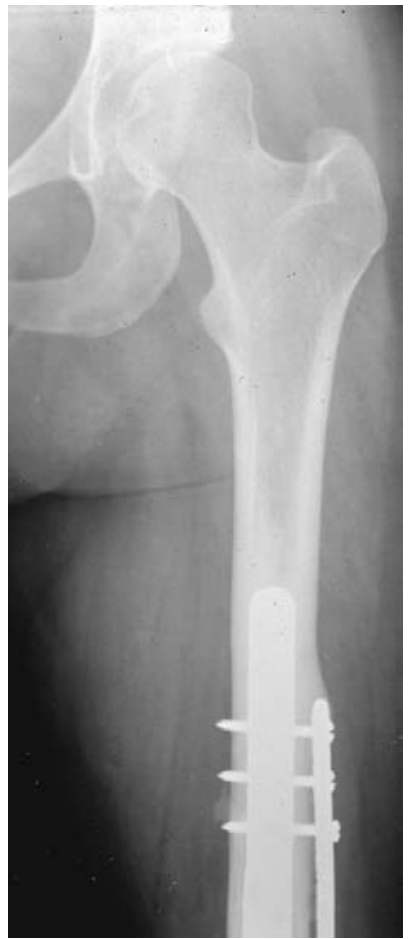

Fig. 1a

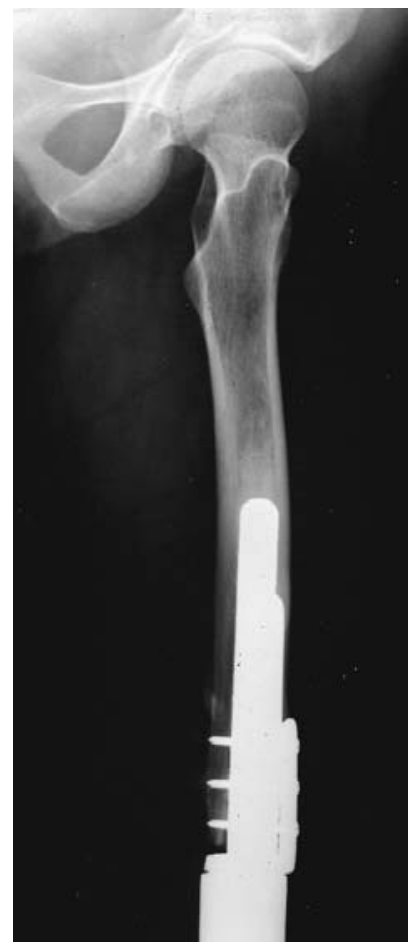

Fig. 1b

cytotoxic chemotherapy. One of these died from sepsis (case 14) and the other (case 10) still has draining fistulae.

Although the complete exchange of all replacement parts is recommended ${ }^{13,18}$ and it has been reported that patients who retain their prosthesis after treatment for infection have unsatisfactory results, ${ }^{13}$ we performed one-stage revision without exchange of the anchorage components (Fig. 1). In all our patients, infection was localised within the scar tube and did not invade the medullary canal. This may explain our success in most of our patients. Septic loosening of anchorage components is likely only in cases of chronic infection.

The emotional acceptance of limb-salvage procedures is confirmed by the fact that this gave the best result for a single criterion (4.8 \pm 0.4 Enneking points), with lower scores for pain $(4.0 \pm 0.8)$, support $(3.6 \pm 1.8)$, walking ability $(3.6 \pm 0.9)$, function $(2.8 \pm 1.2)$ and gait $(2.5 \pm$ 1.3).

One-stage revision failed in four of our patients. Of the two with draining fistulae at follow-up, one with decayed teeth acquired the infection during cytotoxic chemotherapy, and the other had insufficient soft-tissue cover after wide excision due to the irradiation of a rhabdomyosarcoma which preceded a radiation-induced osteosarcoma. Both are still taking antibiotics and both refuse further surgery.

Our series of 18 had an overall success rate (absence of infection for more than six months) of $77.8 \%$ which is similar

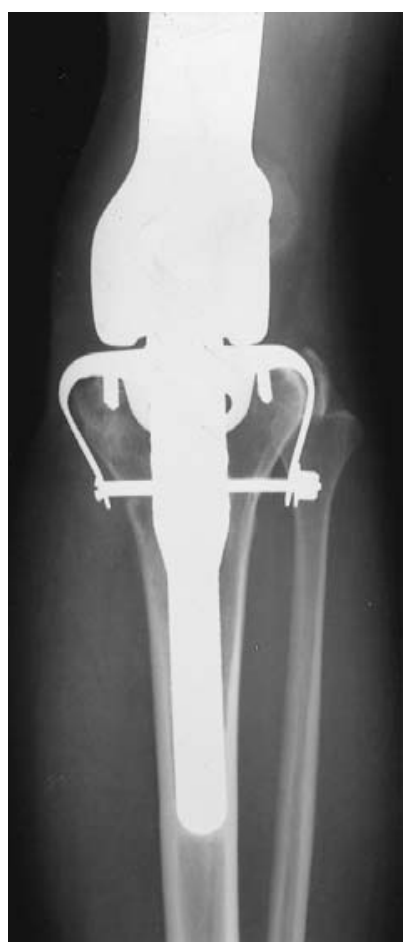

Fig. 1c

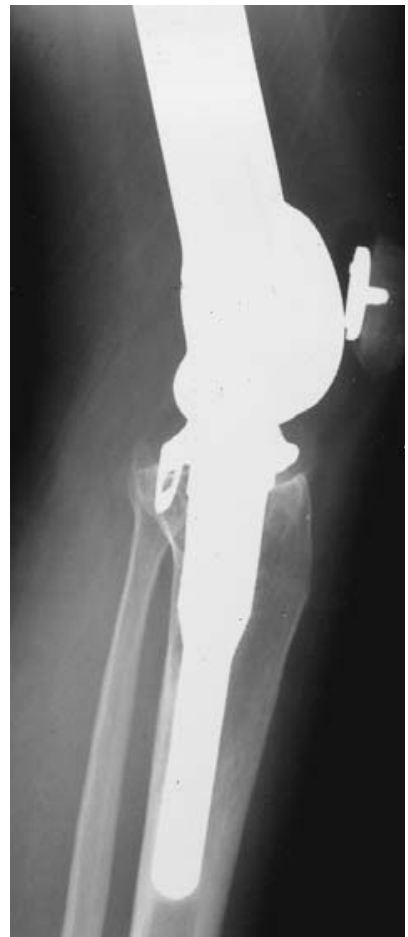

Fig. 1d

Case 15. AP (a,c) and lateral $(b, d)$ radiographs 105 months after revision for an infected megaprosthesis to show anchorage in the femur and tibia. 
to the $82.4 \%$ reported for 18 patients by Grimer et al. ${ }^{38}$

Our results suggest that the one-stage revision of infected megaprostheses without exchange of anchorage components is a sensible and useful choice for patients with antibiotic-sensitive micro-organisms. Two-stage revision should be used as a salvage procedure in case of failure, or for patients with micro-organisms resistant to antibiotics.

We acknowledge the technical assistance of Mrs T. Zettl and the secretarial expertise of Mrs H. Hitschmann with thanks.

Although none of the authors have received or will receive benefits for personal or professional use from a commercial party related directly or indirectly to the subject of this article, benefits have been or will be received but are directed solely to a research fund, foundation, educational institution, or other non-profit institution with which one or more of the authors is associated.

\section{REFERENCES}

1. Marcove RC. The treatment of malignant bone tumors by conservative surgery. Recent Results Cancer Res 1976;54:218-20.

2. Chao EY, Sim FH. Modular prosthetic system for segmental bone and joint replacement after tumor resection. Orthopedics 1985;8:641-51.

3. Kotz R, Ritschl P, Trachtenbrodt J. A modular femur tibia reconstruction system. Orthopaedics 1986;9:1639-52.

4. Kuo KN, Gitelis S, Sim FH, et al. Segmental replacement of long bones using titaniium fiber metal composite following tumor resection. Clin Orthop 1983;176:108-14.

5. Roberts P, Chan D, Grimer RJ, Sneath RS, Scales JT. Prosthetic replacement of the distal femur for primary bone tumors. J Bone Joint Surg [Br] 1991;73-B:762-9.

6. Shih LY, Sim FH, Pritchard DJ, Rock MG, Chao EY. Segmental total knee arthroplasty after distal femoral resection for tumor. Clin Orthop 1993;292;269-81.

7. Enneking WF, Mindell ER. Observations on massive retrieved human allografts. J Bone Joint Surg [Am] 1991;73-A:1123-42.

8. Mankin HJ, Fogelson FS, Trasher AZ, Jaffer F. Massive resection and allograft replacement in the treatment of malignant bone tumors. N Engl J Med 1976;294:1247-55.

9. Mankin HJ, Doppelt SH, Sullivan TR, Tomford WW. Osteoarticular and intercalary allograft transplantation in the management of malignant tumors of bone. Cancer 1982;50:613-30.

10. Kotz R, Salzer M. Rotation-plasty for childhood osteosarcoma of the distal part of the femur. J Bone Joint Surg [Am] 1982;64-A: 959-69.

11. Kotz R, Ritschl P, Kropej D, Capanna R. Cementless modular prostheses: basic concepts and evolution. Chir Organi Mov 1990;75(1 Suppl):177-8.

12. McDonald DJ, Capanna R, Gherlinzoni $F$, et al. Influence of chemotherapy on perioperative complications in limb salvage surgery for bone tumors. Cancer 1990;65:1509-16.

13. Capanna R, Morris HG, Campanacci D, Del Ben M, Campanacci M. Modular uncemented prosthetic reconstruction after resection of tumours of the distal femur. J Bone Joint Surg [Br] 1994;76-B: $178-86$.

14. Eckhardt JJ, Eilber FR, Rosen G, et al. Endoprosthetic replacement for stage IIB osteosarcoma. Clin Orthop 1991;270:202-13.

15. Gradinger R, Rechl H, Ascherl R, Hipp E. Complications and their management following limb-salvage with total knee replacement. In: Brown KLB, ed. Complications of limb salvage: prevention, management and outcome. 6th International, ISOLS Symposium Montreal 1991, ISOLS: Montreal, 1991:151-3.
16. Sim FH, Beauchamp CP, Chao EYS. Reconstruction of musculoskeletal defects about the knee for tumour. Clin Orthop 1987;221: 188-201.

17. Zwart HJJ, Taminiau AHM, Schimmel JW, van Horn JR. Kotz modular femur and tibial replacement: 28 tumor cases followed for 3 (1-8) years. Acta Orthop Scand 1994;65:315-8.

18. Antti-Poika I, Santavirta S, Konttinen YT, Honkanen V. Outcome of the infected hip arthroplasty. Acta Orthop Scand 1989;60:670-5.

19. Babst R, Jenny H, Morscher E. Treatment of infected hip joint arthroplasty. Orthopäde 1989;18:517-26.

20. Burger RR, Basch T, Hopson CN. Implant salvage in infected total knee arthroplasty. Clin Orthop 1991;273:105-12.

21. Fitzgerald RH Jr. Infections of hip prostheses and artificial joints. Infect Dis Clin North Am 1989;3:329-38.

22. Hope PG, Kristinsson KG, Norman P, Elson RA. Deep infection of cemented total hip arthroplasties caused by coagulase-negative staphylococci. J Bone Joint Surg [Br] 1989;71-B:851-5.

23. McDonald DJ, Fitzerald RH, Ilstrup DM. Two-stage reconstruction of a total hip arthroplasty because of infection. J Bone Joint Surg [Am] 1989;71-A:828-34.

24. Morrey BF, Westholm F, Schoifet S, Rand JA, Bryan RS. Longterm results of various treatment options for infected total knee arthroplasty. Clin Orthop 1989;248:120-8.

25. Buchholz HW. Megaprosthesis and infection after total hip prosthesis. Acta Orthop Belg 1986;52:360-7.

26. Göksan SB, Freeman MAR. One-stage reimplantation for infected total knee arthroplasty. J Bone Joint Surg [Br] 1992;74-B:78-82.

27. Loty B, Postel M, Evrard J, et al. One-stage revision of infected total hip replacement with replacement of bone loss by allografts. Int Orthop 1992;16:330-8.

28. Raut VV, Siney PD, Wroblewski BM. One-stage revision of infected total hip replacements with discharging sinuses. J Bone Joint Surg [Br] 1994;76-B:in press.

29. Schneider R. The infected total prosthesis. Orthopäde 1989;18: 527-32.

30. von Foerster G, Klüber D, Käbler D, Kabler U. Mid- to long-term results after tretament of 118 cases of periprosthetic infections after knee joint replacement using one-stage exchanage surgery. Orthopäde 1991;20:244-52.

31. Wroblewski BM. One-stage revision of infected cemented total hip arthroplasty. Clin Orthop 1986;211:103-7.

32. Winkler K, Bielack SS, Delling G, et al. Treatment of osteosarcoma: experience of the co-operative osteosarcoma study group (COSS). Cancer Treat Res 1993;62:269-77.

33. Jürgens H, Exner U, Gadner H, et al. Multidisciplinary treatment of primary Ewing's sarcoma of bone: a 6-year experience of European Cooperative trial. Cancer 1988;61:23-32.

34. Koscielniak E, Jürgens H, Winkler K, et al. Treatment of soft tissue sarcoma in childhood and adolescence: a report of the German Cooperative Soft Tissue Study. Cancer 1992;70:2557-67.

35. Rosen G. Preoperative (neoadjuvant) chemotherapy for osteogenic sarcoma: a ten year experience. Orthopedics 1985;8:659-64

36. Enneking WF, Dunham W, Gebhardt MC, Malawar M, Pritchard DJ. A system for the functional evaluation of reconstructive procedures after surgical treatment of tumours of the musculoskeletal system. Clin Orthop 1993;286:241-6.

37. Glasser D, Langlais F. The ISOLS Radiological Implants Evaluation System. In: Langlais F, Tomeno B, eds. Limb Salvage: major reconstructions in oncologic and nontumoral conditions. Berlin, etc: Springer Verlag, 1991:23-31.

38. Grimer RJ, Carter SR, Sneath RS. Two stage revision for infected endoprostheses. Procs 8th ISOLS, Florence, 1995:54. 